\title{
Pengelolaan Sampah Rumah Tangga Di Kelurahan Bentiring - Kecamatan Muara Bangkahulu - Bengkulu
}

\section{Domestic Waste Management in Bentiring - Muara Bangkahulu Subdistrict - Bengkulu}

\author{
Alwina Sucita, Dinda Lestari, dan Ahmad Walid \\ Program Studi IImu Pengetahuan Alam, Fakultas Tarbiyah dan Tadris, Institut Agama Islam \\ Negeri Bengkulu, 65144, Indonesia
}

Email: alwinasucita5@gmail.com

\begin{abstract}
Abstrak. Pembuangan sampah rumah tangga tidak pada tempatnya di sekitar rumah ataupun ke sungai telah menjadi kebiasaan sebagian masyarakat di daerah Bentiring, sehingga menimbulkan beberapa penyakit yang berbasis lingkungan serta mencemari Sungai. Oleh karena itu, maka perlu dilakukan suatu kajian tentang pengelolaan sampah rumah tangga berdasarkan aspek teknis operasional, kelembagaan, pembiayaan, hukum/peraturan serta peran serta masyarakatnya. Penelitian analitik observasional ini bertujuan untuk mengkaji pengelolaan sampah rumah tangga dan faktor-faktor yang berkorelasi, serta merencanakan pengelolaan sampah rumah tangga yang berbasis masyarakat. Hasilnya didapatkan rata-rata sampah rumah tangga yang dihasilkan sebanyak 1,46 liter/orang/hari atau 0,38 $\mathrm{kg} /$ orang/hari, yang terdiri dari $47 \%$ sampah organik, $15 \%$ kertas, $22 \%$ plastik, serta $16 \%$ logam dan sebagainya. Pengelolaan sampah rumah tangga di daerah bentiring belum dilaksanakan secara optimal. perilaku terhadap kebersihan lingkungan, pengetahuan tentang perda persampahan, serta kesediaan membayar retribusi sampah berkorelasi positif dengan cara pengelolaan sampah rumah tangga. Saran yang diberikan di antaranya peningkatan pelayanan persampahan, pembentukan kelompok pengelola persampahan desa, pelibatan masyarakat dan swasta dalam pembiayaan, peningkatan koordinasi lintas sektoral dan pelibatan tokoh masyarakat dan tokoh agama, serta penerapan peraturan persampahan secara tegas.
\end{abstract}

Kata Kunci; Masyarakat; Pengelolaan; Sampah rumah tangga

\section{Pendahuluan}

Sampah adalah sisa kegiatan sehari- hari manusia dan/atau dari proses alam yang berbentuk padat (Suyoto, 2008). Laju produksi sampah terus meningkat, tidak saja sejajar dengan laju pertumbuhan penduduk tetapi juga sejalan dengan meningkatnya pola konsumsi masyarakat. Di sisi lain kapasitas penanganan sampah yang dilakukan masyarakat maupun pemerintah daerah belum optimal. Sampah yang tidak dikelola dengan baik akan berpengaruh terhadap lingkungan dan kesehatan masyarakat sekitarnya.

Sampah organik adalah sampah yang berasal dari alam, seperti sisa makanan atau daun. Dengan kata lain, 
semua sampah yang dapat terurai dengan mudah adalah sampah organik. Sementara sampah plastik, karet, kaca dan kaleng masuk ke dalam kategori sampah anorganik. Sampah anorganik baiknya dibuang di tempat yang memiliki alat pelebur plastik atau alat daur ulang.

Cara mengelola sampah rumah tangga organik yang paling mudah adalah dengan membuatnya menjadi pupuk kompos yang dapat digunakan untuk berkebun. Namun jika anda tidak suka berkebun atau tidak suka dengan aroma yang ditimbulkan selama pembuatan pupuk kompos, anda dapat menyumbangkan sampah organik ke sahabat yang memiliki hobi berkebun atau penjual tanaman. Dengan demikian anda tetap bisa mengelola sampah organik dengan baik.

Daerah bentiring yang sebagian wilayahnya dilalui oleh sungai dipinggir jembatan sebagian masyarakatnya terbiasa membuang sampah secara sembarangan di sekitar jembatan maupun di aliran sungai. Pemerintah kota Bengkulu secara teknis operasional melalui Dinas Tata Kota dan Lingkungan Hidup hanya mengelola sampah yang terletak di Desa sebakul walaupun masih belum optimal, sedangkan untuk sampah rumah tangga belum dilaksanakan pengelolaannya. Di daerah tersebut

\section{Metode}

Penelitian ini menggunakan
desain analitik observasional. Hubungan antar variabel bebas dengan variabel tergantung dipelajari dengan melakukan pengukuran sesaat untuk kemudian dilakukan uji korelasi (Sastroasmoro dan Ismael, 1995). sudah disediakan 2 buah TPS dengan kondisi terbuka.

Pengangkutan ke TPA hanya dilakukan setiap 3 hari sekali (terkadang lebih dari 3 hari) sehingga tumpukan sampah sudah melebihi kapasitas TPS. Kelembagaan yang diberi wewenang mengelola sampah saat ini hanya Dinas Lingkungan Hidup, Tata Kota dan Perdesaan, namun organisasi atau Lembaga Swadaya Masyarakat yang peduli lingkungan belum ada yang berminat menangani sampah. Aspek pembiayaan pengelolaan sampah yang disediakan melalui APBD masih belum mencukupi. Peraturan Daerah No. 5 tahun 2004 tentang Retribusi Pelayanan Persampahan atas Penyelenggaraan Kebersihan dan Pengelolaan Persampahan belum dijalankan secara optimal.

Menurut Bebassari (2008), secara umum terdapat lima aspek penting dalam pengelolaan sampah yaitu teknologi, institusi, hukum/peraturan, pembiayaan dan partisipasi masyarakat. Penelitian analitik observasional ini bertujuan untuk mengkaji pengelolaan sampah rumah tangga dan faktor-faktor yang berkorelasi, serta merencanakan pengelolaan sampah rumah tangga yang berbasis masyarakat.
Variabel bebas terdiri dari ; tingkat pendidikan, tingkat pendapatan keluarga, perilaku terhadap kebersihan lingkungan, kesediaan membayar retribusi sampah, dan pengetahuan tentang Perda persampahan, dimana Kota Bengkulu mengeluarkan Peraturan 
daerah No 2 tahun 2011 tentang pengelolaan sampah sebagai keseriusanya dalam mengatasi permasalah sampah di kota Bengkulu. Berangkat dari hal tersebut Penulis melakukan penelitian dengan judul implementasi Peraturan Daerah Nomor 2 Tahun 2011 Tentang Pengelolaan Sampah di Kota Bengkulu. Fokus dalam penelitian ini adalah Implementasi kebijakan Peraturan Daerah No 2 Tahun 2011 Kota Bengkulu tentang pengelolaan sampah di kota Bengkulu. Variabel tergantung adalah cara pengelolaan sampah rumah tangga.

Lokasi penelitian di bentiring kota Bengkulu bulan April 2020. Populasi adalah semua rumah tangga yang ada di wilayah Bentiring. Sampel diambil dengan mengunakan rumus Krejcie dan Morgan (1970) dalam Mantra (2004) yaitu : terdiri dari 16 desa. Pengambilan sampel dilakukan dengan proportional sampling method. Selanjutnya dipilih sampel berdasarkan metode simple random sampling di

\section{Hasil dan Pembahasan}

\section{Pengelolaan Sampah Rumah Tangga di Bentiring Kecamatan Muara Bangkahulu}

Aspek Kelembagaan. Pengelolaan sampah di bentiring dilakukan oleh Dinas Lingkungan Hidup, Tata Kota dan Perdesaan pada Bidang Kebersihan melalui Seksi Kebersihan dan Pertamanan. Keterlibatan pihak swasta yang diharapkan dalam kegiatan operasional persampahan meliputi tahap pengangkutan, pengelolaan serta pembuangan akhir, namun sampai saat ini belum ada yang ikut berpartisipasi. setiap desa yang telah ditetapkan jumlah sampel rumahnya.

Data primer didapatkan dengan kuesioner dan wawancara langsung kepada ibu rumah tangga, karena mereka yang lebih banyak berperan dalam mengurus kegiatan rumah tangga termasuk dalam hal pengelolaan sampahnya. Data sekunder merupakan data yang didapatkan daerah bentiring, Dinas Lingkungan Hidup, Tata Kota dan Perdesaan, Analisis data dilakukan dengan uji korelasi Spearman yang bertujuan untuk mengetahui faktorfaktor mana saja yang berkorelasi dengan cara pengelolaan sampah rumah tangga. Untuk merencanakan pengelolaan sampah rumah tangga di bentiring dilakukan dengan tujuh langkah perencanaan (the seven step magic of planning) menggunakan matrik SWOT.

Aspek Hukum dan Peraturan. Adapun Aspek- Aspek yang di teliti terhadap implementasi peraturan daerah No 2 Tahun 2011 kota Bengkulu adalah aspek tehnik operasioanal pengelolaan sampah, aspek pembiayaan, aspek kelembagaan dan aspek peran serta masyarakat.

\begin{tabular}{lll} 
Aspek & Teknis & \multicolumn{2}{c}{ Operasional. } \\
Timbulan sampah & rata-rata tiap \\
rumah tangga sebesar & 1,46 \\
liter/orang/hari atau $0,38 \mathrm{~kg} /$ orang/hari, \\
setara dengan kategori SNI & $19-3964-$ \\
1994 untuk satuan timbulan sampah \\
kota sedang/kecil. Komposisi
\end{tabular}


sampahnya terdiri dari : $47 \%$ sampah organik, $15 \%$ kertas, $22 \%$ plastik, serta $16 \%$ logam dan sebagainya. Sekitar $54,7 \%$ rumah tangga yang memiliki pewadahan, namun hanya $9 \%$ yang melakukan pemilahan. Pengetahuan dan penerapan konsep 3R (Reduce, Reuse dan Recycle) secara sederhana dilakukan oleh $35 \%$ rumah tangga, misalnya menggunakan produk isi ulang, menggunakan kembali kantong plastik tempat belanja, dan membuat vas bunga dari plastik.

\section{Aspek Pembiayaan.}

Pendanaan bersumber pada APBD (Anggaran Pendapatan dan Belanja Daerah). Hal ini tentunya belum mencukupi untuk menunjang kegiatan pengelolaan sampah, karena secara ideal dana yang diperlukan sekitar 5$10 \%$ dari APBD.

\section{Aspek Peran Serta Masyarakat.}

Aspek ini sangat penting dalam melaksanakan pengelolaan sampah sesuai dengan perencanaan yang dilakukan. Merubah perilaku masyarakat adalah hal yang cukup sulit, namun jika dilakukan pembinaan secara terus-menerus maka hasilnya akan didapatkan walaupun perlu waktu puluhan tahun. Adapun tingkat cara pengelolaan sampah rumah tangga sekitar $44 \%$ dikategorikan kurang, dengan penilaian pada ketersediaan pewadahan, pemilahan sampah dan penerapan konsep 3R secara sederhana. Masyarakat sudah terbiasa membuang sampah sembarangan di sekitar rumahnya ataupun ke sungai, sehingga tingkat perilaku terhadap kebersihan lingkungan dikategorikan buruk (67\%). Menurut Notoatmojo (1985) bentuk operasional perilaku terbagi dalam tiga jenis yaitu pengetahuan, sikap dan tindakan.
Faktor-faktor yang Berkorelasi dengan Cara Pengelolaan Sampah Rumah Tangga

Tingkat Pendidikan. Sebagian besar responden (53\%) berpendidikan rendah (tidak sekolah, SD sederajat). Hasil uji korelasi Spearman menunjukkan nilai signifikansi $<0,05$ sehingga Ho ditolak, dengan koefisien korelasi sebesar 0,669. Hal ini berarti tingkat pendidikan berkorelasi positif dengan pengelolaan sampah rumah tangga. Menurut Hadiwiyoto (1983), kebodohan merupakan salah satu faktor yang menimbulkan masalah sampah. Jalan yang ditempuh dalam upaya meningkatkan kesadaran masyarakat agar mengelola sampah hasil produksinya setiap hari salah satunya dengan meningkatkan pengetahuan masyarakat melalui pendidikan formal maupun non formal.

\section{Tingkat Pendapatan. Didapatkan}

sekitar $60 \%$ responden berada pada tingkat pendapatan yang rendah (< 1 juta perbulan). Hasil uji korelasi Spearman menunjukkan nilai signifikansi < 0,05 maka Ho ditolak, dengan koefisien korelasi sebesar 0,603. Hal ini berarti tingkat pendapatan keluarga berkorelasi positif dengan cara pengelolaan sampah rumah tangga. Artinya sesuai dengan pendapat Neolaka (2008), kemiskinan membuat orang tidak peduli dengan lingkungan. Orang dalan keadaan miskin dan lapar, pusing dengan kebutuhan keluarga, pendidikan dan lain-lain, bagaimana dapat berpikir tentang peduli lingkungan. Misalnya tidak mampu menyediakan pewadahan atau tempat sampah di rumah tangga karena faktor ketidakmampuan secara ekonomi. 
$\begin{array}{lll}\text { Perilaku terhadap Kebersihan } & \text { Ke }\end{array}$

Lingkungan. Hasil uji korelasi

Spearman menunjukkan nilai signifikansi < 0,05 maka Ho ditolak, dengan koefisien korelasi sebesar 0,65. Hal ini berarti perilaku terhadap kebersihan lingkungan berkorelasi positif dengan cara pengelolaan sampah rumah tangga. Perilaku dalam bentuk operasionalnya terbagi atas pengetahuan, sikap dan tindakan (Notoatmojo ,1985). Kebiasaan masyarakat yang berperilaku hidup bersih dan sehat (PHBS) salah satunya tidak membuang sampah secara sembarangan. Menurut Menurut Pramudya (2001) dalam Susilo (2008), terdapat dua jenis bencana akibat rusaknya daya dukung lingkungan. Pertama, kerusakan karena faktor internal yakni kerusakan yang berasal dari alam sendiri. Kedua, kerusakan karena faktor eksternal yaitu kerusakan lingkungan yang berasal dari perilaku manusia, seperti limbah rumah tangga yang dibuang di sungai-sungai. Menurut Hadiwiyoto (1983), sikap mental atau perilaku merupakan salah satu faktor yang menimbulkan masalah sampah, sehingga sukar untuk dikendalikan.

Pengetahuan tentang Perda

Persampahan. Hasil uji korelasi Spearman menunjukkan nilai signifikansi < 0,05 maka Ho ditolak, dengan koefisien korelasi sebesar 0,646. Hal ini berarti pengetahuan tentang peraturan daerah persampahan berkorelasi positif dengan cara pengelolaan sampah rumah tangga. Selama ini belum optimal dalam mensosialisasikan Perda No. 2 tahun 2011 kepada masyarakat luas, sehingga banyak masyarakat tidak mengetahuinya. Jika peraturan tersebut benar-benar ditegakkan tentunya hal ini akan memberikan efek jera terhadap masyarakat yang melanggarnya. Penegakkan hukum ini akan memberikan dampak positif terhadap pengelolaan sampah rumah tangga yang lebih baik. Menurut Soemarwoto (2004), di negeri ini penegakan hukum sangat lemah. Peraturan banyak yang dilanggar, misalnya pembuangan sampah di sungai dan selokan, dapat berjalan tanpa tindakan nyata dari aparat penegak hukum. Salah satu sebab utamanya ialah adanya KKN (korupsi, kolusi dan nepotisme) yang merebak karena dorongan untuk mendapatkan dana yang besar guna mendukung pola hidup yang mewah. Padahal menurut Hadi (2005), dalam konteks lingkungan hidup, hukum diharapkan menjadi pedoman agar tata kehidupan kita ini mendasarkan pada prinsip-prinsip kelestarian lingkungan.

Kesediaan Membayar Retribusi Sampah. Hasil uji korelasi Spearman menunjukkan nilai signifikansi < 0,05 maka Ho ditolak, dengan koefisien korelasi sebesar 0,577. Hal ini berarti kesediaan membayar retribusi berkorelasi positif dengan cara pengelolaan sampah rumah tangga. Di bentiring belum dilakukan pelayanan persampahan sehingga masyarakat belum diwajibkan membayar retribusi sampah rumah tangga. Namun beberapa masyarakat yang menyadari akan pentingnya kebersihan lingkungan bersedia membayar retribusi asal mendapatkan pelayanan pengelolaan sampah oleh pemerintah. Mereka berusaha mengelola sampah rumah tangganya secara mandiri, walaupun wilayahnya belum mendapatkan pelayanan persampahan. Menurut Reksohadiprodjo dan Brodjonegoro (1982), teknik pengeluaran preventif mengestimasi nilai minimum kualitas 
lingkungan berdasarkan kesediaan orang mengeluarkan biaya untuk menghilangkan atau paling tidak mengurangi akibat buruk lingkungan.

\section{Perencanaan Pengelolaan Sampah Rumah Tangga Berbasis Masyarakat}

Suatu kegiatan akan dapat berjalan secara efektif dan efesien jika dilakukan melalui sebuah perencanaan yang matang. Perencanaan merupakan proses dasar yang digunakan untuk memilih tujuan dan menentukan bagaimana cara mencapainya. Pengelolaan sampah berbasis masyarakat di bentiring dapat diterapkan dengan menggunakan perencanaan yang bertipe Transaktif atau Pembelajaran Sosial. Adapun langkah- langkah yang dilakukan meliputi : identifikasi masalah, penentuan tujuan, penilaian situasi, alternatif kebijakan/program, pemilihan alternatif, keputusan dan implementasi, serta evaluasi dan monitoring.

Agar dapat diperoleh hasil analisis yang lengkap dan akurat maka diperlukan suatu metode, salah satunya adalah matrik SWOT (Strength, Weakness, Opportunities, dan Treath). Menurut Rangkuti (2003), matrik ini dapat menggambarkan secara jelas bagaimana peluang dan ancaman eksternal yang dihadapi dapat disesuaikan dengan kekuatan dan kelemahan yang dimiliki. Analisis matrik SWOT dapat dilihat pada Tabel 1.

Dalam melakukan pengelolaan sampah berbasis masyarakat di Kecamatan Muara Bangkahulu, dapat diputuskan kebijakan/program kerja pada aspek teknisoperasional dan peran serta masyarakatnya. Adapun pola pengelolaannya dapat digambarkan sebagai berikut:

\section{Pola Pengelolaan Sampah Berbasis} Masyarakat

Peran serta masyarakat secara aktif dalam pengelolaan sampah rumah tangga sangat menentukan keberhasilan pelaksanaannya. Masyarakat perlu diberdayakan dengan segala upaya yang bersifat non instruktif guna meningkatkan pengetahuan dan kemampuan masyarakat agar mampu mengidentifikasi masalah, merencanakan dan melakukan penyelesaian masalah dengan memanfaatkan potensi masyarakat setempat tanpa bergantung pada bantuan dan luar. 
Tabel 1. Matrik SWOT Pengelolaan Sampah Rumah Tangga

\begin{tabular}{|c|c|c|}
\hline Faktor Eksternal & PELUANG & ANCAMAN \\
\hline Faktor Internal & & \\
\hline KEKUATAN & $\begin{array}{l}\text { 1. Sosialisasi perda } \\
\text { persampahan } \\
\text { 2. Fasilitasi } \\
\text { pengelolaan sampah } \\
\text { rumah tangga } \\
\text { 3. Koordinasi dengan } \\
\text { instansi lain }\end{array}$ & $\begin{array}{l}\text { 1. Penyiapan sarana teknis } \\
\text { operasional } \\
\text { 2. Penerapan konsep } 3 R \\
\text { 3. Pembuatan kompos skala } \\
\text { rumah tangga }\end{array}$ \\
\hline KELEMAHAN & $\begin{array}{l}\text { 1. Sanksi hukum yang } \\
\text { tegas } \\
\text { 2. Meningkatkan } \\
\text { partisipasi masyarakat }\end{array}$ & $\begin{array}{l}\text { 1. Mengupayakan keterlibatan } \\
\text { pihak swasta } \\
\text { 2. Meningkatnkan kinerja aparat } \\
\text { pengelola sampah }\end{array}$ \\
\hline
\end{tabular}

Pola pemberdayaan masyarakat yang dibutuhkan bukan kegiatan yang sifatnya top-down intervention yang tidak menjunjung tinggi aspirasi dan potensi masyarakat untuk melakukan kegiatan swadaya, akan tetapi yang paling dibutuhkan masyarakat lapisan bawah terutama yang tinggal di desa adalah pola pemberdayaan yang sifatnya bottom-up intervention. Dimulai dengan menghargai dan mengakui bahwa masyarakat lapisan bawah memiliki potensi untuk memenuhi kebutuhannya, memecahkan permasalahannya, serta mampu melakukan usaha-usaha produktif dengan prinsip swadaya dan kebersamaan.

Pola pendekatan yang paling efektif untuk memberdayakan masyarakat adalah the inner resources approach. Pola ini menekankan pentingnya merangsang masyarakat untuk mampu mengidentifikasi keinginan-keinginan dan kebutuhankebutuhannya sendiri dan bekerja secara kooperatif dengan pemerintah dan badan- badan lain untuk mencapai kepuasan bagi mereka. Pola ini mendidik masyarakat menjadi peduli akan pemenuhan dan pemecahan masalah yang mereka hadapi dengan menggunakan potensi yang mereka miliki (Riasmini, 2006).

Pengelolaan merupakan suatu siklus yang membentuk loop atau gelung (Gambar 2.), sehingga tahap evaluasi dan monitoring merupakan tahapan untuk menilai semua langkah yang telah dilakukan untuk memperoleh model pengelolaan yang lebih baik lagi.

Dalam evaluasi dan monitoring ini faktor waktu mempunyai pengaruh yang penting karena dapat menentukan keberhasilan dan kegagalan dari tiap tahap yang dilaksanakan. Evaluasi dan monitoring ini merupakan umpan balik untuk memperbaiki langkah-langkah yang telah dilakukan.

Penduduk daerah Bentiring pada tahun 2008 berjumlah 39.507 jiwa, dengan produksi sampah ratarata $\quad 0,00146 \quad \mathrm{~m}^{3} /$ orang/hari. Diperkirakan volume timbulan sampah yang dihasilkan sebanyak $57,68 \mathrm{~m}^{3} /$ hari atau $21.0532, \mathrm{~m}^{3} /$ tahun . Menggunakan rata-rata pertumbuhan penduduk $0,57 \%$ per tahunnya. 


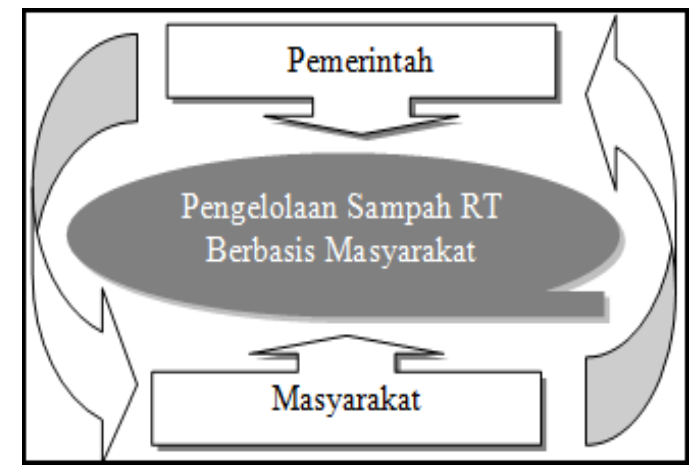

Gambar 1. Gelung Proses Evaluasi dan Monitoring

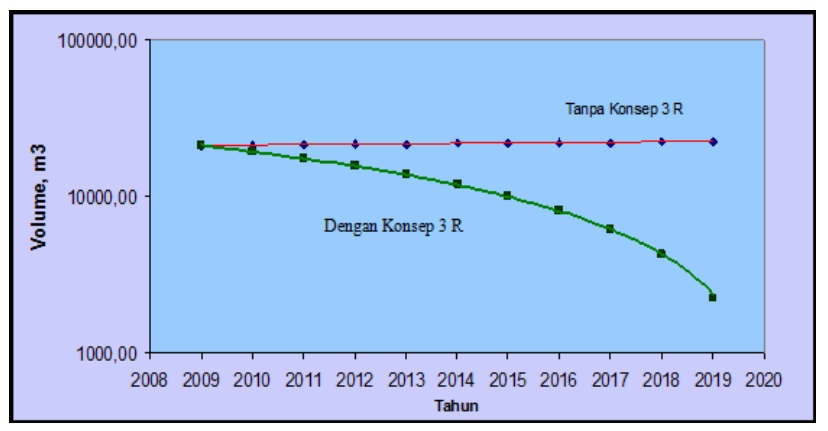

Gambar 2. Perkiraan Penurunan Timbulan Sampah Rumah Tangga

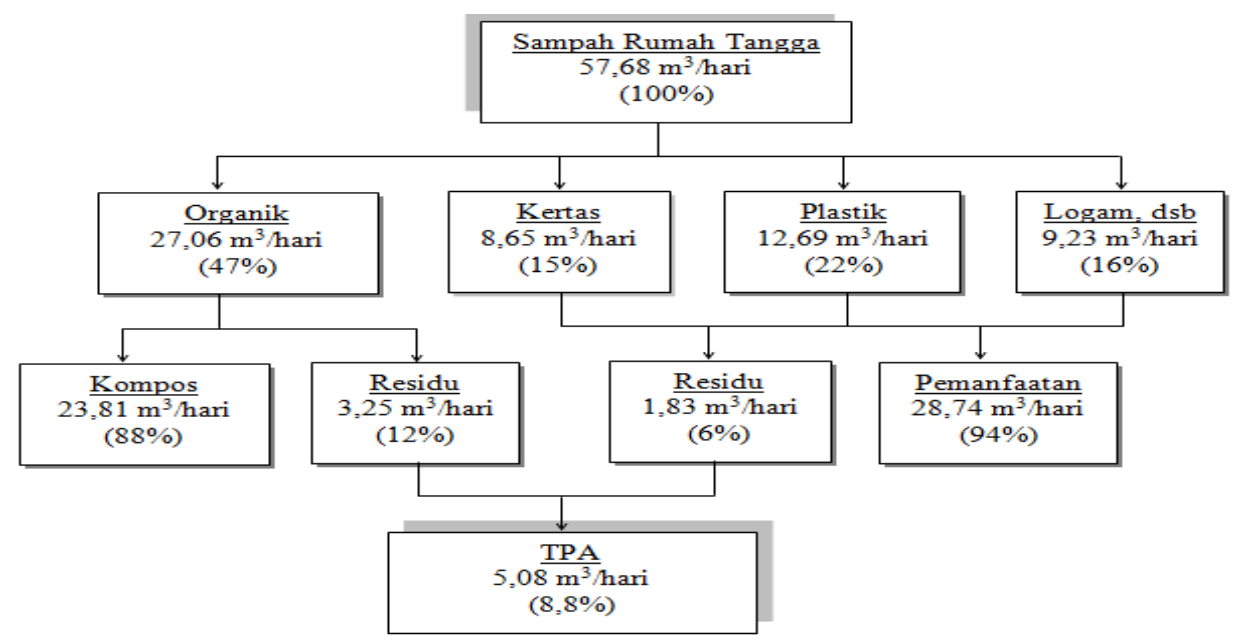

Gambar 3. Neraca Persentase Sampah Rumah Tangga

Tabel 2. Nilai Ekonomis Sampah Rumah Tangga

\begin{tabular}{|l|r|r|r|r|}
\hline \multicolumn{1}{|c|}{ Jenis Sampah } & $\begin{array}{c}\text { Timbulan } \\
(\mathrm{Kg})\end{array}$ & $\begin{array}{c}\text { Perbulan } \\
(\mathrm{Kg})\end{array}$ & $\begin{array}{c}\text { Perkiraan } \\
\text { Harga }(\mathrm{Rp} / \mathrm{Kg})\end{array}$ & $\begin{array}{c}\text { Nilai Ekonomis } \\
(\mathrm{Rp})\end{array}$ \\
\hline Organik (kompos) & 0,65 & 19,60 & 750 & 14.699 \\
\hline Kertas & 0,21 & 6,26 & 1.000 & 6.255 \\
\hline Plastik & 0,31 & 9,17 & 1.500 & 13.761 \\
\hline Logam, dsb & 0,22 & 6,67 & 1.250 & 8.340 \\
\hline Ju m la h & 1,39 & 41,70 & & 43.055 \\
\hline
\end{tabular}

Dengan menerapkan konsep 3R diasumsikan akan terjadi penurunan timbulan sampah $9 \%$ setiap tahunnya, sebagaimana terlihat pada Gambar 2. Berdasarkan volume timbulan sampah yang dihasilkan sebanyak $57,68 \mathrm{~m}^{3} /$ hari maka setelah dilakukan pemilahan 
berdasarkan jenisnya akan didapatkan volume sampah organik $27,06 \mathrm{~m}^{3} / \mathrm{hari}$, kertas $8,65 \mathrm{~m}^{3} /$ hari, plastik 12,69 $\mathrm{m}^{3} /$ hari, serta logam dan sebagainya $9,23 \mathrm{~m}^{3} /$ hari. Jika residu pembuatan kompos dari sampah organik diperkirakan $12 \%$, sedangkan residu pemanfaatan sampah non organik sebesar $6 \%$ maka volume sampah yang dibuang ke TPA hanya sekitar $5,08 \mathrm{~m}^{3} /$ hari (Gambar 3).

Usaha pemanfaatan sampah merupakan komponen penting dalam pengelolaan sampah yang dapat mengurangi dampak lingkungan. Ditinjau dari segi ekonomi, maka sampah rumah tangga dapat dimanfaatkan berdasarkan jenisnya. Sampah organik dapat dijadikan kompos sedangkan sampah plastik, kertas, logam dan sebagainya dapat dijual ataupun dibuat kerajinan daur ulang. Berdasarkan jumlah sampah yang dimanfaatkan maka dapat dihitung nilai ekonomis dari setiap rumah tangga yang menerapkan prinsip 3R terhadap sampahnya. Berat timbulan sampah rata- rata sekitar $0,38 \mathrm{~kg} /$ orang/hari. Jika rumah tangga terdiri dari 4 orang maka berat sampahnya mencapai 1,52 $\mathrm{kg} /$ rumah/hari. Dikurangi dengan residu maka sampah yang dapat dimanfaatkan sekitar $91,2 \%$ atau 1,39 $\mathrm{kg} / \mathrm{rumah} /$ hari. Berdasarkan hal

\section{Simpulan}

Pengelolaan sampah rumah tangga di kecamatan Muara Bangkahulu belum dilaksananakan secara optimal.

Tingkat pendidikan, tingkat pendapatan keluarga, perilaku terhadap kebersihan lingkungan, tersebut, nilai ekonomis dari sampah yang dimanfaatkan untuk kompos dan dijual berdasarkan jenisnya bagi setiap rumah tangga per bulannya sebesar Rp. 43.055,- sebagaimana terdapat Tabel 2.

Dalam konsep ini eko mempunyai arti efisiensi eko-nomi dan efisiensi ekologi. Efisiensi berarti menggunakan sumber daya ekonomi seefektif mungkin untuk memenuhi kebutuhan dan keinginan manusia sehingga tidak ada sumber daya yang terbuang. Upaya daur ulang sampah merupakan salah satu faktor kunci dalam konsep eko-efisiensi (EE). Konsep EE pertama kali diperkenalkan pada tahun 1992 oleh World Business Council for Sutainable Development (WBCSD) dalam publikasinya Changing Course. WBCSD telah mengidentifikasikan adanya tujuh faktor kunci dalam ekoefisiensi, yaitu : mengurangi jumlah penggunaan bahan, mengurangi jumlah penggunaan energi, mengurangi pencemaran, memperbesar daur ulang bahan, memaksimalkan penggunaan SDA yang dapat diperbarui, memperpanjang umur pakai produk, serta meningkatkan intensitas pelayanan (Kementrian Negara LH, 2007). $\begin{array}{lcr}\text { pengetahuan } & \text { tentang } & \text { peraturan } \\ \text { persampahan } & \text { dan } & \text { kesediaan } \\ \text { membayar retribusi sampah } & \text { sampar } \\ \text { berkorelasi positif dengan cara } & \\ \text { pengelolaan sampah rumah tangga. }\end{array}$

Tipe perencanaan yang dapat diterapkan dalam pengelolaan sampah rumah tangga di bentiring 
adalah transaktif atau pembelajaran sosial. Dimulai dengan pemenuhan kebutuhan teknis operasional yaitu pewadahan dan pengomposan rumah tangga, pemilahan sampah komunal, tempat pengumpulan sampah desa untuk didaur ulang, serta TPS kecamatan. Kemudian meningkatkan peran serta masyarakat melalui pemberdayaan dan pendampingan oleh pengelola persampahan dan instansi terkait lainnya.

\section{Daftar Pustaka}

1. Bebassari, S. 2008. Integrated Municipal Solid Waste Management toward ZERO WASTE Approach Center For Assesment and Application of Environmental Technology. Jakarta. (http://www.pudsea.ugm.ac.id/document/bebassari.pdf)

2. Bagoes, I. M. 2004. Filsafat Penelitian dan Metode Penelitian Sosial. Yogyakarta: Pustaka Belajar.

3. Hadi, S. P. 2005. Dimensi Lingkungan: Perencanaan Pembangunan Gadjah Mada University Press. Yogyakarta.

4. Hadiwiyoto, S. 1983. Penanganan dan Pemanfaatan Sampah. Yayasan Idayu. Jakarta.

5. Kementrian Negara LH. 2007. Panduan Penerapan Eko-Efisiensi Usaha Kecil dan Menengah Sektor Batik. Kerjasama Kementrian Negara LH dan Deutsche Gesselschaft fuer Technische Zusammenarbeit (GTZ) GmbH dalam kerangka Program Lingkungan Hidup Indonesia - Jerman (Pro LH). Jakarta.

6. Neolaka, A. 2008. Kesadaran Lingkungan. Rineka Cipta. Jakarta.

7. Notoatmojo, S. 1985. Pengantar IImu Perilaku. Fakultas Kesehatan Masyarakat Ul. Jakarta.

8. Reksohadiprodjo, S dan Brodjonegoro, A.B.P. 1982. Ekonomi Lingkungan : Suatu Pengantar. BPFE. Yogyakarta.

9. Riasmini, M. 2006. Peran Tenaga Kesehatan Dalam Pemberdayaan Masyarakat Untuk Mewujudkan Desa Siaga. Badan Pengembangan dan Pemberdayaan SDM Kesehatan Depkes. Jakarta.

10. Sastroasmoro, S dan Ismael, S. 2000. Dasar-dasar Metodologi Penelitian Klinis. Bagian Fakultas Kedokteran UI. Jakarta. 
11. SNI, 1994. Metode Pengambilan dan Pengukuran Contoh Timbulan dan Komposisi Sampah Perkotaan (SNI 19-3964-1994). Badan Standar Nasional. Jakarta.

12. Soemarwoto, O. 2004. Atur Diri Sendiri :Paradigma Baru Pengelolaan Lingkungan Hidup. Gadjah Mada University Press. Yogyakarta.

13. Susilo, R. K. $\quad$ D. 2008. Sosiologi Lingkungan. PT. Raja Grafindo Persada, Jakarta.

14. Suyoto, B. 2008. Rumah Tangga Peduli Lingkungan. Prima Media, Jakarta.

15. Rangkuti, F. 2003. Analisis SWOT Teknik Membedah Kasus Bisnis. Gramedia Pustaka Utama. Jakarta. 